\title{
Kazimierz Dagnan: POLSKI NAROdOWY SOCJALISTA
}

Słowa kluczowe: Kazimierz Dagnan, biografistyka, narodowy socjalizm, myśl polityczna

Keyword s: Kazimierz Dagnan, biography, national socialism, political thought

\begin{abstract}
Kazimierz Dagnan (1891-1986) was an extraordinary, but practically forgotten today, figure. The activist of the independence conspiracy before the World War I, and the Piłsudski's legionnaire had an almost archetypal biography for a generation of fighters for independence. In independent Poland, he found himself in the government administration, but he did not limit himself to an administrative career. He followed his own path, faithful to your ideals connecting the cause of Polish independence with the idea of the emancipation of the working class. He was active on the pro-Piłsudski wing of the National Workers' Party (NWP), and after the coup d'etat in 1926 he became involved in the splinter pro-regime NWP-Left group. He was an ideologist of the national workers' movement, stubbornly trying to radicalize him. Making a synthesis of nationalism, democracy and reformist socialism, he created the original Polish national-socialist ideology. This ideology assumed the construction of a "People's Poland of Labour" as a democratic state in which grassroots socialization of the means of production and exchange would gradually proceed. The priority for Dagnan still was the sovereignty of the Polish state and the primacy of the Polish (ethnic) nation in this state. The political expression of this ideology was the Party of National Socialists created in 1933, which, however, did not succeed and vegetated on the margins of political life. During World War II, Dagnan returned to his native Nowy Sącz. In People's Poland, he began a second life there - as an artist and social activist valued in the local community.
\end{abstract}


ワ $\perp$ jarzy się nieodmiennie $\mathrm{z}$ rasistowskim, totalitarnym i ludobójczym reżimem Trzeciej Rzeszy, który przyniósł światu ogrom nieszczęść. Należy jednak pamiętać, że przed II wojną światową pojęcie to było dużo pojemniejsze, niosło niejednoznaczną treść. Narodowy socjalizm był po prostu - w opozycji do socjalizmu internacjonalistycznego marksistowskiej na ogół proweniencji - próbą połączenia idei patriotyzmu z hasłami reform społecznych. W międzywojennej Czechosłowacji liberalna Partia Narodowo-Socjalistyczna ( ̌̌eskoslovenská strana národně socialistická) była jednym z filarów ładu demokratycznego.

Również w Polsce narodowy socjalizm ukształtował się na długo przed Hitlerem jako nurt o lewicowym i demokratycznym charakterze. Patronem tego ruchu był Bolesław Limanowski. Pod jego wpływem Stanisław Barański, jeden z przywódców zaburzeń studenckich na Uniwersytecie Warszawskim w 1883 r., utworzył w 1888 r. w Paryżu Gminę Narodowo-Socjalistyczną (później Polska Narodowo-Socjalistyczna Partia). W krajowym Związku Młodzieży Polskiej (tzw. Zet) istniała grupa „narodowych socjalistów” ze Stanisławem Wojciechowskim na czele, która w 1891 r. przystąpiła do Zjednoczenia Robotniczego Edwarda Abramowskiego. W Galicji w 1902 r. pojawił się Związek Niezawisłych Narodowych Socjalistów, założony przez byłych członków Polskiej Partii Socjalno-Demokratycznej: Andrzeja Lipińskiego i Józefa Puczkę $^{1}$. Najwybitniejszym ideologiem polskiego narodowego socjalizmu był Kazimierz Dagnan.

\section{Życie}

Kazimierz Dagnan urodził się 8 maja 1891 r. w Malcu (Tarnowskie) jako syn Józefa, kierownika szkoły powszechnej w Nowym Sączu, i Kunegundy Padé. Protoplastą rodu miał być napoleoński oficer Gabriel d’Agnan, który osiedlił się w Tarnowie w 1812 r. Kazimierz uczęszczał do II c.-k. Gimnazjum w Nowym

1 Szerzej zob. J. Tomasiewicz, Rewolucja Narodowa. Nacjonalistyczne koncepcje rewolucji społecznej w Drugiej Rzeczypospolitej, Warszawa 2013, s. 130-134. 
Sączu². Już w szkole ujawnił swe społecznikowskie pasje jako członek zarządu Czytelni Młodzieży Rękodzielniczej, założonej przez Towarzystwo Szkoły Ludowej3. Należał też wówczas do młodzieżowej konspiracji tzw. „duchowców”, zainicjowanej w 1906 r. przez Kazimierza Ducha ${ }^{4}$. Grupa ta, współtworzona również m.in. przez Bronisława Pierackiego, Antoniego Benisza i Józefa Kustronia, wydawała pismo „Teka”. Pod względem ideowym była zbliżona do Narodowej Demokracji, a organizacyjnie związana z Zetem ${ }^{5}$.

W 1910 r. Dagnan zdał maturę, a po ukończeniu gimnazjum podjął studia na wydziale prawa Uniwersytetu Jagiellońskiego ${ }^{6}$. W tym samym roku sądecka organizacja Zetu, przyjąwszy program niepodległościowy, zerwała z endecją i zasiliła szeregi „Zarzewia” - lewicującej frondy z obozu narodowego7. Deklaracja zarzewiaków głosiła, że „Sprawa emancypacji ludu jest sprawą przyszłości narodu. [...] droga do wyzwolenia i sprawiedliwości społecznej prowadzi przez Niepodległą Polskę Ludową"8. Można powiedzieć, że ideom tym Dagnan pozostał wierny do końca. Zarzewie powiązane było z innymi rozłamowymi grupami endeckimi, w tym z Narodowym Związkiem Robotniczym, w którego szeregach Dagnan niebawem się odnalazł. Już w 1912 r. - jako przedstawiciel NZR - wszedł w skład Tymczasowej Komisji Skonfederowanych Stronnictw Niepodległościowych ${ }^{9}$.

2 A. Sitek, Kazimierz Dagnan (1891-1986), „Rocznik Sądecki”, t. XXV, 1997, s. 274-275 .

3 T. Aleksander, Życie społeczne i przemiany kulturalne Nowego Sacza w latach 1870-1990, Kraków 1993, s. 92, 138.

4 M. Gawryszczak, Bronisław Wilhelm Pieracki (1895-1934). Biografia polityczna. Łódź 2014, s. 15.

5 J. Krupa, Zarys pracy niepodległościowej w Nowym Saczu, „Rocznik Sądecki” 1939, t. I, s. 159. Dodać można, że siostra Kazimierza Aleksandra, założycielka żeńskiego oddziału strzeleckiego, została żoną przyszłego gen. Kustronia. A. Szczepanek, Z. Kubrak, Generał Józef Kustroń, „Rocznik Sądecki” 2011, t. XXXIX, s. 332.

6 R. Gessing, Zarys dziejów II gimnazjum w Nowym Sączu w okresie galicyjskim (l. 1908-1918), „Rocznik Sądecki” 1971, t. XII, s. 161; A. Sitek, Kazimierz...

7 A. Szczepanek, Z. Kubrak, Generat..., s. 331; T. Monasterska, Narodowy Zwiqzek Robotniczy 1905-1920, Warszawa 1973, s. 91.

8 Zarzewie 1909-1920. Wspomnienia i materiaty, oprac. A. Garlicka, Warszawa 1973, s. 356-357.

9 A. Garlicka, Sosnowiecka "Iskra” w sprawozdaniach Kazimierza Dagnana (I-II 1915), „Rocznik Historii Czasopiśmiennictwa Polskiego” 1965, t. 4, z. 1, s. 230. 
W tym samym roku w Nowym Sączu „duchowcy” połączyli się z socjalistyczną grupą Promienistych w organizację Jastrzębie ${ }^{10}$. Owocem tego porozumienia było utworzenie w październiku 1912 r. Komitetu Obywatelskiego (z udziałem m.in. Dagnana), który w grudniu utworzył X Drużynę Strzelecką. Sekretarzem Związku Strzeleckiego w Nowym Sączu został Kazimierz Dagnan ${ }^{11}$.

Autor biogramu Dagnana twierdzi, że po wybuchu I wojny światowej wstąpił on do 1. Pułku Piechoty Legionów ${ }^{12}$, jednak brak informacji o jego udziale w działaniach bojowych. Wiadomo natomiast, że Dagnan zgłosił swój udział w pracach Naczelnego Komitetu Narodowego. Przydzielony do Departamentu Wojskowego NKN, Dagnan był funkcjonariuszem biura werbunkowego w randze sierżanta w Sosnowcu ${ }^{13}$, a zarazem od listopada 1914 r. członkiem Komisariatu Zagłębiowskiego Polskiej Organizacji Narodowej (politycznej przybudówki Polskiej Organizacji Wojskowej). Działalność PON w Zagłębiu opierała się na współpracy NZR i PPS, co zapewne pogłębiło radykalizm Dagnana ${ }^{14}$. Później pełnił funkcję oficera werbunkowego w Miechowie i pracował jako członek redakcji „Dziennika Narodowego” w Biurze Prasowym Departamentu Wojskowego NKN w Piotrkowie ${ }^{15}$. W rodzinnym Nowym Sączu należał do działającego tam w latach 1915-1916 Powiatowego Komitetu Narodowego ${ }^{16}$. Publikował też w prasie NZR: w „Głosie Robotnika” (Łódź 1915-1916), „Iskrze” (Sosnowiec 1915-1917), „Wiadomościach Robotniczych” (Warszawa 1916-1921 $)^{17}$.

10 M. Gawryszczak, Bronisław..., s. 15.

11 J. Krupa, Zarys..., s. 175.

12 A. Sitek, Kazimierz...

13 A. Garlicka, Sosnowiecka..., s. 230.

14 J. Z. Pająk, Z dziejów Polskiej Organizacji Narodowej (wrzesień - grudzień 1914), „Kieleckie Studia Historyczne” 1996, t. 14, s. 111; T. Monasterska, Narodowy..., s. 101.

15 Legionista Polski. Kalendarz N.K.N. na rok 1916, s. XXXVII-XXXVIII; A. Garlicka, Organizacja akcji prasowej Naczelnego Komitetu Narodowego, „Rocznik Historii Czasopiśmiennictwa Polskiego" 1964, t. 3, z. 2, s. 130.

16 T. Duda, Powiatowy Komitet Narodowy w Nowym Saczu w latach 1915-1916, „Rocznik Sądecki” 2008, t. XXXVI, s. 261.

17 A. Garlicka, Sosnowiecka..., s. 230. 
W lipcu 1916 r. Dagnan wraz z innymi zwolennikami Piłsudskiego podał się do dymisji w Departamencie Wojskowym NKN ${ }^{18}$. Pozostał jednak w szeregach Legionów jako oficer kancelaryjny w Krajowym Inspektoracie Zaciągu do Wojska Polskiego, 1 stycznia 1917 r. awansowany do stopnia chorążego ${ }^{19}$. W 1917 r. zawarł też związek małżeński z Janiną Schneigert, utalentowaną malarką, i zamieszkał w należącej do rodziny żony charakterystycznej willi (tzw. „chiński domek”) przy al. Wolności 18, zwanej później „dagnanówką”20.

Dagnan pozostawał aktywistą Narodowego Związku Robotniczego. Duża fluktuacja bazy członkowskiej Związku sprawiła, że dostrzegł potrzebę wychowania ideowego w organizacji (np. w „Wiadomościach Robotniczych” we wrześniu 1918 r.). Oznaczało to konieczność wypracowania przez NZR własnej ideologii, odpowiadającej środowiskom robotniczym, a zarazem odmiennej niż marksistowska, endecka czy chadecka. W czerwcu 1918 r. zaczęła ukazywać się w Warszawie pod redakcją Dagnana „Sprawa Robotnicza”, na łamach której opublikowano cykl artykułów ideologicznych (prawdopodobnie jego autorstwa) „Nasze cele i drogi”. Sformułowany tu program NZR wykraczał poza obronę doraźnych interesów robotników w ramach systemu kapitalistycznego, za cel stawiał sobie obalenie kapitalizmu przez „przewrót społeczny od dołu” ${ }^{21}$. W ślad za tym na zjeździe NZR w październiku 1918 r. frakcja Dagnana (m.in. A. Benisz, W.L. Evert, E. Samborski) zgłosiła wniosek o zmianę nazwy organizacji na Narodowa Partia Socjalistyczna; choć upadł, to nastąpiła radykalizacja programu ${ }^{22}$. Inspiracją ideologii narodowo-socjalistycznej stał się kooperatyzm Edwarda Abramowskiego jako alternatywny wobec marksistowskiego modelu socjalizmu. Uznanie spółdzielczości za drogę transformacji społecznej doprowadziło Dagnana do współpracy z radykalną lewicą: w listopadzie 1918 r. wziął udział w konferencji kooperatyw proletariackich, postulującej budowę bezpartyjnego klasowego ruchu spółdzielczego i znalazł się w komisji organizacyjnej Sekretariatu spółdzielni robotniczych

18 T. Monasterska, Narodowy..., s. 129.

19 Lista starszeństwa oficerów Legjonów Polskich w dniu oddania Legjonów Polskich Wojsku Polskiemu (12 kwietnia 1917). Warszawa 1917, s. 72.

20 Z. Beiersdorf, B. Krasnowolski, Przekształcenia urbanistyczne, architektura i sztuka, [w:] Dzieje miasta Nowego Sącza, t. II, Kraków 1993, s. 555.

21 T. Monasterska, Narodowy..., s. 236, 244-246.

22 Z historji polskiego Narodowego Socjalizmu: 30-lecie powstania Narodowego Związku Robotniczego, „Narodowy Socjalista” 1935, nr 8. 
(należeli do niej również Jan Hempel, Stanisław Szwalbe-Jaskułowski, Bronisław Siwik, Antoni Szczerkowski) ${ }^{23}$.

W Zarządzie Głównym NZR Dagnan wraz z Bolesławem Fichną reprezentował skrzydło radykalne ${ }^{24}$. Akceptował istnienie Rad Delegatów Robotniczych pod warunkiem ich odpartyjnienia i przekształcenia w rady pracy ${ }^{25}$. Uważał jednak, że słabe wyrobienie klasy robotniczej uniemożliwia jej na tym etapie samodzielne przejęcie władzy, dlatego uznając lewicowy rząd Moraczewskiego, domagał się poszerzenia jego składu ${ }^{26}$. Opowiadał się za zawarciem strategicznego sojuszu z ludowcami, o konsolidacji stronnictw chłopskich w czerwcu 1919 r. pisał entuzjastycznie jako „pierwszym kroku do stworzenia w Sejmie większości ludowo-robotniczej”27.

Zachowywał natomiast dystans wobec Narodowego Stronnictwa Robotników - połączenie NZR z bardziej konserwatywna partią z dawnego zaboru pruskiego uniemożliwiało przyjęcie radykalnego kursu. Pod wpływem Dagnana NZR na swym XVII zjeździe w czerwcu 1919 r. uznał istnienie walki klasowej i proklamował „dążenie do uspołecznienia środków produkcji [...] w miarę dojrzewania warunków gospodarczych i technicznych wyszkolenia proletariatu" ${ }^{28}$. Idee te były nie do przyjęcia dla działaczy z Poznańskiego ${ }^{29}$. Choć Dagnan należał do komisji porozumiewawczej NZR-NSR i jeździł agitować do Wielkopolski, to równocześnie krytykował posłów NSR za współpracę $z$ endecką prawicą ${ }^{30}$. Polemika $\mathrm{z}$ Narodowym Stronnictwem Robotników w kwestii reformy rolnej doprowadziła do ustąpienia Dagnana z redakcji

23 Wł. Wolert, Ruch współdzielczy, „Przedświt” 1919, nr 1-2; por. K. Dębiec [K. Dagnan], Narodowy ruch robotniczy jego rola w życiu Polski i proletariatu polskiego, Warszawa 1922, s. 51-52; A. Laska, Narodowa Partia Robotnicza 1920-1937. Studia z dziejów ruchów społecznych w Drugiej Rzeczypospolitej. Rzeszów 2004, s. 175, 177.

24 T. Monasterska, Narodowy..., s. 298.

25 K. Dębiec, RDR, „Sprawa Robotnicza” 1919, nr 14.

26 K. Dębiec, Narodowy ruch..., s. 32.

27 Dak, Nowy układ sił w Sejmie, „Sprawa Robotnicza” 1919, nr 39; por. I. Malinowska, Polskie centrum parlamentarne w latach 1919-1926, „Przegląd Historyczny” 1990, nr 3-4, s. 586, 608.

28 T. Monasterska, Narodowy..., s. 372.

29 A. Laska, Narodowa..., s. 73.

30 A. Laska, Działalność Narodowej Partii Robotniczej na terenie Małopolski w latach 1920-1937, „Zeszyty Naukowe Politechniki Rzeszowskiej” 2005, nr 224 [seria: Ekonomia i Nauki Humanistyczne z. 15], s. 74; T. Monasterska, Narodowy..., s. 385. 
„Sprawy Robotniczej” w sierpniu 1919 r. ${ }^{31}$ Mimo to na XVIII zjeździe NZR w maju 1920 r. grupa Dagnana po raz kolejny wystąpiła z radykalnym projektem, domagając się utworzenia „umiarkowanej narodowej i demokratycznej partji socjalistycznej"32.

Choć próba pchnięcia narodowego ruchu robotniczego na narodowo-socjalistyczne tory poniosła fiasko, Dagnan pozostał działaczem powstałej w maju 1920 r. Narodowej Partii Robotniczej. Był członkiem Rady Naczelnej NPR, stał na czele warszawskich struktur partii ${ }^{33}$. Otwierał warszawską listę NPR, kandydując bezskutecznie w wyborach do Sejmu w $1922 \mathrm{r} .^{34}$ Jako redaktor „Sprawy Robotniczej” i autor broszury „Narodowy ruch robotniczy i jego rola w życiu Polski i proletariatu polskiego" (1922) pełnił rolę partyjnego ideologa ${ }^{35}$. Dużą wagę przywiązywał do działalności kulturalno-oświatowej wśród robotników ${ }^{36}$. Już w 1919 r. pracował w Głównym Wydziale Kulturalno-Oświatowym NZR, później został prezesem utworzonego w styczniu 1923 r. Polskiego Towarzystwa Kultury i Oświaty Robotniczej „Pochodnia”37. Pod względem politycznym związany był z piłsudczykami ${ }^{38}$. Choć opowiadał się za współpracą z ludowcami, to na III zjeździe NPR w maju 1923 r. sprzeciwił się poparciu rządu Chjeno-Piasta ${ }^{39}$.

31 DK, Posłowie NSR - pod komendq reakcji, „Sprawa Robotnicza” 1919, nr 44; Czy my katolicy możemy głosować za Narod. Partją Robotniczą, "Głos Rolnika” 1922, nr 45; Cz. Demel, J. Krawulski, K. Rzepa, Działalność Narodowego Stronnictwa Robotników i Narodowej Partii Robotniczej w Wielkopolsce w latach 1917-1937. Warszawa-Poznań 1980, s. $79-80$.

32 Z historji...; Cz. Demel, J. Krawulski, K. Rzepa, Działalność..., s. 99.

33 A. Laska, Narodowa..., s. 231; H. Przybylski, Chrześcijańska Demokracja i Narodowa Partia Robotnicza w latach 1926-1937, Warszawa 1980, s. 49.

${ }^{34}$ Ludwik Hass, Wybory warszawskie 1918-1926. Postawy polityczne mieszkańców Warszawy w świetle wyników glosowania do ciat przedstawicielskich. Warszawa 1972, s. 130.

35 Enpeerowskie karty, „Łodzianin” 1924, nr 23.

${ }^{36}$ K. Dębiec, Narodowy ruch..., s. 52.

37 A. Laska, Narodowa..., s. 185-187; Ruch zawodowy w Polsce. Zarys dziejów, red. S. Kalabiński, Warszawa 1974, t. II cz. II, s. 153.

${ }_{38}$ Cz. Demel, J. Krawulski, K. Rzepa, Działalność..., s. 124.

39 K. Dagnan, Walka czy współdziałanie robotniczo-chtopskie, „Sprawa Robotnicza" 1922, nr 17; A. Laska, Narodowa..., s. 230. 
W tym czasie Dagnan pracował w departamencie zatrudnienia Ministerstwa Pracy i Opieki Społecznej, m.in. publikując w resortowym periodyku „Praca i Opieka Społeczna” ${ }^{40}$. Na Zjeździe Kas Chorych w 1925 r. reprezentował już Okręgowy Urząd Ubezpieczeń w Warszawie ${ }^{41}$. Na świat przychodziły jego kolejne dzieci: Jan (1918), Kazimiera (1920), Zofia (1925) i Roman $(1930)^{42}$.

W czasie przewrotu majowego Dagnan przebywał w Warszawie, opowiadając się wraz z Antonim Ciszakiem po stronie Piłsudskiego ${ }^{43}$. Zaraz po zamachu zaangażował się w budowę piłsudczykowskiej frakcji w NPR. W czerwcu 1926 r. założył „Nową Sprawę Robotniczą” jako organ wewnątrzpartyjnej opozycji, w sierpniu uczestniczył w zjeździe wojewódzkim w hotelu „Boulevard" w Poznaniu, na którym powstała pierwsza regionalna struktura NPR-Lewicy, we wrześniu w zjeździe NPR w Łodzi ${ }^{44}$. Na I kongresie NPR-Lewicy 3 X 1926 r. został wybrany członkiem władz naczelnych partii i komisarzem na dawną Kongresówkę ${ }^{45}$. Na stronę rozłamowców przeciągnął towarzystwo „Pochodnia”46. Będąc zwolennikiem połączenia propiłsudczykowskich ugrupowań robotniczych (NPR-Lewicy, PPS dawnej Frakcji Rewolucyjnej i Generalnej Federacji Pracy), współpracował z pismem GFP „Solidarność Pracy”" ${ }^{\text {". Jego }}$ aktywność spotkała się z zarzutem socjalistycznego „Robotnika”, że został oddelegowany przez władze do rozbijania ruchu zawodowego ${ }^{48}$.

Fakt, że Dagnan nadal pracował w administracji państwowej (jako zastępca dyrektora Okręgowego Urzędu Ubezpieczeń w Warszawie), po przewrocie nabierał nowego wymiaru. Cieszył się zaufaniem zwierzchników, skoro w 1931 r.

40 K. Dagnan, Pracownicze zwiq̨zki zawodowe w Polsce w roku 1921, „Praca i Opieka Społeczna” 1922, z. 1; por. Jan Malański, Pracownicze związki zawodowe w Polsce. Warszawa 1934, s. 115; A. Sitek, Kazimierz....

41 Zjazd Kas Chorych, „Polak” 1925, nr 172.

42 A. Sitek, Kazimierz...; Nowy Sącz w 2010 roku, „Rocznik Sądecki” 2011, t. XXXIX, s. 483.

43 A. Laska, Narodowa..., s. 286; por. A. Dębiec [K. Dagnan], Narodowy socjalizm. Pabianice 1930, s. 36.

44 A. Laska, Narodowa..., s. 276, 281-282.

45 Cz. Demel, J. Krawulski, K. Rzepa, Działalność..., s. 211.

46 Wielki kongres „Orlęcia” w Częstochowie, „Praca” 1929, nr 50.

47 A. Dębiec, Narodowy..., s. 37; K. Dagnan, Zarys historji ruchu zawodowego w Polsce, „Solidarność Pracy” 1927, nr 1.

48 W sprawie insynuacyj „Robotnika”, „Solidarność Pracy” 1927, nr 1. 
przemawiał w Częstochowie w imieniu ministra pracy Hubickiego ${ }^{49}$. W czerwcu 1928 r. został dodatkowo komisarzem w Kasie Chorych w Kaliszu, w marcu 1934 r. członkiem Zarządu Głównego Funduszu Bezrobocia ${ }^{50}$. W marcu 1932 r. został odznaczony Krzyżem Niepodległości51 .

Dagnan nie był usatysfakcjonowany obliczem ideowym NPR-Lewicy i nie ustawał w wysiłkach, by przyjęła kurs narodowo-socjalistyczny. Radykalizacja nastrojów w dobie Wielkiego Kryzysu sprzyjała tym zamierzeniom. Na zlecenie A. Ciszaka Dagnan opracował „Program Narodowej Partii Socjalistycznej”, który został wiosną 1932 r. przyjęty przez komisję Rady Naczelnej ${ }^{52}$. Przeciw temu projektowi wystąpiła jednak umiarkowana frakcja Ludwika Waszkiewi$\mathrm{Cza}^{53}$. Kongres, planowany początkowo na czerwiec, został odroczony do października, a Ciszak i Fichna zmienili zdanie pod naciskiem organizacji łódzkiej i poznańskiej ${ }^{54}$. W rezultacie w październiku 1932 r. kongres większością 43:100 przyjął nazwę Narodowego Stronnictwa Pracy i program, który „zbytnio nie odbiegał od programu NPR z 1921 r." ${ }^{\text {55 }}$.

W tej sytuacji środowisko skupione wokół założonego w lipcu 1932 r. miesięcznika „Narodowy Socjalista” (złożone, jak napisał K. Dagnan, z elementów „młodych i ruchliwych”) postanowiło założyć Partię Narodowych Socjalistów. PNS powstała 20 czerwca 1933 r. Do czołowych działaczy należeli Antoni Szadkowski (urzędnik Ministerstwa Opieki Społecznej) jako sekretarz generalny i Erazm Samborski (b. członek komisji robotniczej Związku Młodzieży Polskiej „Zet” i Związku im. Kilińskiego, w 1917 r. wiceprzewodniczący NZR

49 Pomnik ofiar mordu, „Gazeta Powszechna” 1931, nr 258.

50 Sprawozdanie z działalności Funduszu Bezrobocia za rok 1934 i I kwartał 1935. Warszawa MCMXXXV, s. 5; Konferencja z komisarzem powiatowym Kasy Chorych w Kaliszu, „Sprawa Ubezpieczeń Społecznych” 1928, nr 2; Powiatowa Kasa Chorych w Kaliszu, "Samorząd Terytorjalny i Ubezpieczenia Społeczne” (dodatek do „Kuriera Porannego” z 27 czerwca 1929 r.).

51 Zarządzenie Prezesa Rady Ministrów, poz. 82, „Monitor Polski” nr 64 z 18 marca $1932 \mathrm{r}$.

52 Archiwum Akt Nowych [dalej AAN], zespół Ministerstwo Spraw Wewnętrznych [dalej MSW], sygn. 850, k. 200; Antoni Ciszak. Zarys biograficzny przywódcy wielkopolskich mas robotniczych. Poznań 1938, s. 54.

53 AAN, MSW, sygn. 850, k. 143, 162-163, 256, 271, 302, 317, 339-340.

54 Zmiana nazwy N.P.R.-Lewicy, „Narodowy Socjalista” nr 4-5 (1932).

55 Cz. Demel, J. Krawulski, K. Rzepa, Działalność..., s. 294-296; A. Laska, Narodowa..., s. 367. 
w Rosji $)^{56}$. Sztandarowym ideologiem ruchu był Dagnan, który w pracach organizacyjnych na ogół używał pseudonimu Kazimierz Dębiec - być może trudno było mu pogodzić role ministerialnego urzędnika i lidera radykalnego ruchu politycznego ${ }^{57}$. Dagnan pozostawał w bliskich związkach z sanacyjnym establishmentem politycznym, o czym świadczył choćby fakt jego uczestnictwa w Komitecie Uczczenia Pamięci Medarda Downarowicza w 1935 r. $^{58}$

Partia Narodowych Socjalistów nie spełniła jednak pokładanych w niej nadziei. PNS wegetowała na marginesie życia politycznego, zmuszona do konkurowania $\mathrm{z}$ innymi ugrupowaniami o narodowo-socjalistycznym profilu (zwłaszcza z Narodowo-Socjalistyczną Partią Robotniczą) ${ }^{59}$. W rezultacie Dagnan już w lutym 1935 r. nawiązał kontakty ze Stanisławem Mrozem (przywódcą NSP w Poznaniu) i F. Kwiecińskim (prezesem warszawskiej organizacji NPR), dążąc do reintegracji trzech odłamów narodowego ruchu robotniczego. W październiku 1935 r. trzy partie narodowo-robotnicze zorganizowały wspólną demonstrację, a w lutym 1936 r. utworzyły Narodowy Obóz Pracy. Konferencja zjednoczeniowa w kwietniu 1936 r. zakończyła się jednak fiaskiem - różnice ideologiczne i taktyczne między NPR i PNS okazały się niemożliwe do przezwyciężenia ${ }^{60}$.

56 Stronnictwo Narodowych Socjalistów, „Ilustrowana Republika” 1932, nr 175; Antoni..., s. 55; P.N.S. w walce o Nowq Polskę, „Narodowy Socjalista” nr 9-12 (1933); por. O. Grott, Faszyści i narodowi socjaliści w Polsce. Kraków 2007, s. 76; W. Bujak, Historia Stronnictwa Pracy (1937-1946-1950), Warszawa 1988, s. 65, 243; T. Monasterska, Narodowy..., s. 174, 351 .

57 S. Ciepłowski, Pseudonimy autorów polskich piszących o Warszawie w latach 1795-1944, „Almanach Muzealny” 1997, nr 1, s. 202. Łódzka „Ilustrowana Republika” informację, że pod pseudonimem K. Dębiec ukrywa się dyrektor warszawskiego urzędu ubezpieczeń, podała w tonie sensacji. Stronnictwo nar. socjalistów, „Ilustrowana Republika” 1932, nr 105; por. Radykalizm, szowinizm, antysemityzm, „Ilustrowana Republika” 1932, nr 106; Partja Narodowych Socjalistów, „Ilustrowana Republika” 1932, nr 219; Narodowi socjaliści w Polsce, „Dziennik Białostocki” z 15 IV 1932 r.

58 Uczczenie pamięci Medarda Downarowicza wiceprezesa Zarządu Głównego Z.R., „Naród i Wojsko" 1935, nr 20.

59 Szerzej zob. J. Tomasiewicz, W kierunku nacjokracji. Tendencje autorytarne, totalistyczne i profaszystowskie w polskiej myśli politycznej (1933-1939): narodowcy - narodowi radykałowie - narodowi socjaliści. Katowice 2019, s. 291-294.

60 AAN, MSW, sygn. 853a, k. 13, 148, 240, 254; Ku konsolidacji, „Narodowy Socjalista” nr 2 (1935); Wspaniała manifestacja solidarności robotniczej, „Narodowy Socjalista” 
Porażki doprowadziły do wzmożenia walk wewnętrznych. W 1937 r. miał wybuchnąć konflikt Dagnana (wspieranego przez Antoniego Malatyńskiego i E. Samborskiego) z Szadkowskim - ten drugi był przeciwny „opozycji dla opozycji”. Pokonany Szadkowski, „porzucając pozycję "narodowo-socjalistyczną"", związał się z OZN. Wówczas Malatyński i Samborski zwrócili się przeciw Dagnanowi, który zrezygnował z działalności politycznej ${ }^{61}$. Wiązała się z tym też zmiana w życiu zawodowym Dagnana, który w 1938 r. został przeniesiony ze stanowiska naczelnika wydziału w Ministerstwie Opieki Społecznej na etat dyrektora Wyższego Urzędu Ubezpieczeń w Poznaniu ${ }^{62}$. Przeniesienie ze stolicy na prowincję z pewnością utrudniło aktywność polityczną.

Po wybuchu II wojny światowej Dagnan wrócił do rodzinnego Nowego Sącza, gdzie wspólnie z niejakim Czachowskim prowadził sklep z artykułami gospodarczymi przy ul. Lwowskiej $31^{63}$. W sklepie tym znajdowała się jedna ze „skrzynek” sieci łączności Związku Walki Zbrojnej ${ }^{64}$. Równocześnie Dagnan działał społecznie na polu dobroczynności jako współpracownik powiatowej delegatury Rady Głównej Opiekuńczej ${ }^{65}$.

Po zakończeniu okupacji niemieckiej Dagnan, mieszkający wówczas przy ul. Szwedzkiej $8^{66}$, podjął pracę w administracji terenowej. Pełnił wówczas kolejno funkcje: sekretarza Wydziału Powiatowego, kierownika Referatu Kultury i Sztuki w starostwie powiatowym (1947-1951), referenta prawno-budowlanego w Powiatowym Wydziale Architektury, wreszcie urzędnika Klęczańskich Kamieniołomów Drogowych. Jako pracownik starostwa Dagnan opublikował w 1946 r. Informator o uzdrowiskach, letniskach i turystyce na Sądeckim Podhalu

nr 11 (1935); Zjednoczenie Narodowego Obozu Pracy, „Demokrata” 1935, nr 12; O. Grott, Faszyści..., s. 78-79; A. Laska, Narodowa..., s. 419; H. Przybylski, Chrześcijańska..., s. 277; W. Bujak, Historia..., s. 65, 243.

61 H. Przybylski, Chrześcijańska..., s. 280; Przedwojenny ruch narodowo-socjalistyczny w Polsce, AAN, zespół Delegatura Rządu na Kraj, sygn. 202/II-22, k. 37-38 (dokument ten, pisany prawdopodobnie $\mathrm{z}$ pamięci w okresie okupacji, wymaga ostrożnego podejścia ze względu na liczne błędy).

${ }^{62}$ Nie ma zmian na stanowisku dyrektora U.S., „Nowy Kurjer” 1938, nr 114.

63 A. Sitek, Kazimierz...

64 J. Bieniek, Wojskowy ruch oporu na Sądeczyźnie [sic], „Rocznik Sądecki”, t. XII, 1971, s. 340.

65 T. Aleksander, Życie..., s. 398, 425.

66 Z archiwalnej pótki, „Beskid” 1994, nr 3. 
- pierwszy przewodnik po tych terenach ${ }^{67}$. W 1955 r. przeszedł na emeryturę, ale działał jeszcze w Komisji Regionalnej Sądecczyzny przy Prezydium Powiatowej Rady Narodowej ${ }^{68}$.

Bezpośrednio po wojnie Dagnan próbował działać politycznie w Polskim Stronnictwie Ludowym. W 1948 r. Urząd Bezpieczeństwa podjął wobec niego kontrolę operacyjną, podejrzewając go o współpracę z członkami nielegalnej organizacji Polska Podziemna Armia Niepodległościowa ${ }^{69}$.

Dagnan wierny pozostał swym społecznikowskim pasjom. W 1947 r. wybrano go wiceprezesem Oddziału Polskiego Towarzystwa Tatrzańskiego „Beskid”, dwa lata później prezesem ${ }^{70}$. W 1950 r. brał udział w zjeździe połączeniowym, na którym powstało Polskie Towarzystwo Turystyczno-Krajoznawcze ${ }^{71}$. Jako pasjonat turystyki górskiej był współautorem Słownika geografii turystycznej Polski (Warszawa 1959) ${ }^{72}$. Pełnił też od 1950 r. funkcję przewodniczącego Komisji Opieki nad Zabytkami ${ }^{73}$. W 1956 r. uczestniczył w powołaniu Towarzystwa Przyjaciół Sztuk Pięknych w Nowym Sączu i należał do jego zarządu ${ }^{74}$.

Na emeryturze Dagnan ujawnił również swoje talenty artystyczne. Malował akwarele (głównie pejzaże), pisał opowiadania. W grudniu 1976 r. dostał nagrodę w konkursie dla twórców ludowych w Nowym Sączu. Jako wszechstronny twórca był założycielem i pierwszym prezesem Klubu Twórczego (Klubu Plastyków Nieprofesjonalnych i Twórców Ludowych) w Nowym Sączu.

67 Z archiwalnej półki, „Beskid” 1999, nr 1; Piśmiennictwo, „Wierchy”, t. 18, 1948, s. 325. Jego rozszerzona wersja ukazała się trzy lata później pt. „Sądeczyzna. Krajobraz. Uzdrowiska. Turystyka”. Piśmiennictwo, „Wierchy” t. 19, 1949, s. 266.

68 A. Sitek, Kazimierz...; T. Aleksander, Życie..., s. 458, 473.

69 Sprawa ewidencyjno-obserwacyjna dot. Kazimierz Dagnan, Oddziałowe Archiwum Instytutu Pamięci Narodowej w Krakowie, podzespół Wojewódzki Urząd Spraw Wewnętrznych w Krakowie 1983-1990, sygn. IPN Kr 010/2921.

70 Poczet Prezesów Oddziału PTTK „Beskid” w Nowym Sq̨czu, „Echo Beskidu” 2001, nr 2.

71 Fr. Czuchra, Byłem uczestnikiem Zjazdu Połaczeniowego PTT z PTK, „Echo Beskidu” 1991, nr 3.

72 Bibliografia górska, „Wierchy”, t. 29, 1960, s. 266.

73 J. Wawro, Komisja Opieki nad Zabytkami, „Echo Beskidu” 1991, nr 3.

74 K. Dagnan: Piętnastolecie istnienia i działalności Towarzystwa Przyjaciół Sztuk Pięknych w Nowym Sączu, „Rocznik Sądecki” 1973, t. XIV, s. 665-667; A. Totoń, 50-lecie TPSP w Nowym Saczu, „Almanach Muszyny” 2007, s. 235. 
Został też w 1964 r. kierownikiem galerii obrazów swego szkolnego kolegi Bolesława Barbackiego, któremu poświęcił publikację Bolesław Barbacki wybitny portrecista (Nowy Sącz 1966) ${ }^{75}$. Za swą działalność społeczną otrzymał krzyż kawalerski Orderu Odrodzenia Polski, a także Złoty Krzyż Zasługi, Złotą Tarczę Herbową Nowego Sącza, Złotą Odznakę PTTK, Odznakę Zasłużonego Działacza Kultury ${ }^{76}$.

W latach 80. Dagnan znów zbliżył się do polityki. W 1981 r. znalazł się w Komitecie Honorowym przy Społecznym Komitecie Budowy Pomnika Generała Józefa Kustronia, potem był członkiem Towarzystwa im. gen. Józefa Kustronia $^{77}$. Jeszcze w 1985 r. działacz opozycji antykomunistycznej Jerzy Giza kontaktował się z Dagnanem w sprawie upamiętnień legionistów ${ }^{78}$.

Były to jednak już ostatnie miesiące życia. Kazimierz Dagnan zmarł 11 kwietnia 1986 r. i został pochowany w grobowcu rodzinnym na cmentarzu komunalnym w Nowym Sączu ${ }^{79}$.

75 T. Aleksander, Życie..., s. 474-475, 496; A. Totoń, 50-lecie..., s. 235-236; M. Tarsa-Bielak, Nasza galeria, „Kurier Starosądecki” 2003, nr 133; A. Sitek, Życie kulturalne Sądeczyzny [sic] (1964-1969), „Rocznik Sądecki” 1971, t. XII, s. 475, 490, 492; Kronika, „Polska Sztuka Ludowa - Konteksty” 1977, t. 31, nr 2, s. 124.

76 A. Sitek, Kazimierz...

77 J. Giza, Kustroniowcy, „Almanach Sądecki” 1995, nr 4, s. 53.

78 Tenże, Jak Sącz o swoich katyńczykach pamiętał, „Almanach Sądecki” 2001, nr 3, s. 53.

79 A. Sitek, Kazimierz... 


\section{Myśl - poglądy - koncepcje}

Dagnan uważał, że „każdy naród stanowi samodzielną, odrębną indywidualność kulturalną i duchową”, dlatego „ruchy społeczno-polityczne danego narodu [...] różnić muszą się od ruchów innych narodów" ${ }^{\prime 00}$. Starannie podkreślał w związku z tym rodzime źródła narodowego socjalizmu. Należały do nich: romantyczna filozofia Adama Mickiewicza, myśl polityczna Bolesława Limanowskiego, „filozofia pracy” Stanisława Brzozowskiego, kooperatyzm Edwarda Abramowskiego. Odwoływał się do tradycji radykalnych ugrupowań Wielkiej Emigracji, takich jak Lud Polski i Towarzystwo Demokratyczne Polskie, Gminy Narodowo-Socjalistycznej, Narodowego Związku Robotniczego, PPS-Frakcji Rewolucyjnej, Legionów Piłsudskiego ${ }^{81}$. W ten sposób dagnanowski narodowy socjalizm okazywał się nie tylko rdzennie polski, ale i prekursorski w stosunku do innych ruchów tego typu ${ }^{82}$.

Myśl polityczna Dagnana kształtowała się w polemice z innymi kierunkami ideowymi, z - jak to ujął - ideologiami ,interesu klasowego" i „egoizmu narodowego"83. Głównym przeciwnikiem był marksizm, zwłaszcza w komunistycznym wariancie. Różnice miały charakter fundamentalny - jak pisał „[n]arodowy socjalizm przyznając marksizmowi rację w krytyce ustroju kapitalistycznego [...] nie zgadza się z czysto materialistycznym światopoglądem komunizmu"84. Dagnan twierdził, że teoria Marksa nie sprawdziła się: nie postępuje koncentracja kapitału ani pauperyzacja mas, rozwija się sektor publiczny, prawo pracy, opieka socjalna itd., „[c]zynnik pracy zrównany zostaje w obliczu prawa i państwa z kapitałem"85. Interes narodowy okazuje się waż-

80 A. Dębiec, Narodowy..., s. 39; A. Dębiec, Nasz socjalizm, „Narodowy Socjalista” 1935, nr 1.

81 A. Dębiec, Narodowy..., s. 33, 41-50; K. Dębiec, Narodowy ruch..., s. 45-46; K. Dagnan, Nowe drogi narodowo-społecznego rozwoju. Warszawa 1924, s. 65-66, 77; A. Dębiec, Komunizm bankrutuje!, Warszawa 1937, s. 5-7. Na łamach „Sprawy Robotniczej” publikowano nawet teksty Abramowskiego. E. Abramowski, Rewolucja czy kooperacja, „Sprawa Robotnicza” 1918, nr 8.

82 A. Dębiec, Nasz socjalizm, „Narodowy Socjalista” 1935, nr 1.

83 K. Dębiec, Narodowy ruch..., s. 44.

84 A. Dec, Narodowy socjalizm wobec komunizmu, „Narodowy Socjalista” 1933, nr 3.

85 A. Dębiec, Narodowy..., s. 7-8, 13, 15; K. Dagnan, Nowe..., s. 37-46; A. Dębiec, Komunizm..., s. 11-21. 
niejszy od międzynarodowej solidarności proletariatu ${ }^{86}$. Fałszywe przesłanki marksizmu skutkowały negatywnymi rezultatami. Sowieckiemu komunizmowi zarzucał wyzysk proletariatu, wynarodawianie nierosyjskich mniejszości i brak demokracji ${ }^{87}$. Dagnan pisał, że „[b]olszewizm - to jest [...] również faszyzm [...], więcej krwawy i despotyczniejszy od innych faszyzmów"88.

Wbrew łatwym skojarzeniom narodowy socjalizm Dagnana nie oznaczał powinowactwa z faszyzmem. Dagnan dostrzegał tendencję do syntezy narodowo-socjalnej również w innych krajach, jednak bliskość deklarował tylko z demokratycznymi ugrupowaniami w krajach słowiańskich: Czechosłowacką Partią Narodowo-Socjalistyczną, jugosłowiańską Partią Ludowo-Socjalistyczną (Narodno-socijalistička stranka), Bułgarskim Ludowym Związkiem Chłopskim (Български земеделски народен съюз), rosyjską Partią Socjalistów-Rewolucjonistów (Партия социалистов-революционеров). W stosunku do włoskiego faszyzmu i niemieckiego nazizmu przyznawał, że wyrastają z tych samych korzeni, ale uważał je za formy zdegenerowane („hitlerowcy są przede wszystkiem odwetowcami”) ${ }^{89}$. Po dojściu NSDAP do władzy krytyka hitleryzmu jeszcze zaostrzyła się - Dagnan piętnował Hitlera za „sprzymierzenie się z najbardziej konserwatywnymi żywiołami”, pisał, że nazizm „schodzi do roli ordynarnej bojówki antysocjalistycznej"90.

Ideologia Dagnana miała być „socjalizmem idealistycznym”, który uznawał „świadomą wolę ludzką za najwyższy regulator warunków bytu zbiorowości społecznej”. „Idealizm dziejowy” stanowił fundamentalną różnicę antagonizującą narodowy socjalizm z marksizmem. Prymat idei nad materią prowadził z kolei do woluntaryzmu i aktywizmu: Dagnan wierzył, że „zbiorowa myśl

86 A. Dębiec, Narodowy..., s. 16-19; A. Dębiec, Nasz socjalizm, „Narodowy Socjalista” 1935, nr 2.

87 A. Dębiec, Narodowy..., s. 20-22; A. Dębiec, Komunizm..., s. 26-35, 40-46.

88 A. Dębiec, Komunizm..., s. 53. Odnotować jednak warto, że kilka lat później ocena komunistycznego eksperymentu była już bardziej wyważona. Dagnan konstatował pozytywną ewolucję ku „konstruktywnemu, stopniowemu, ewolucyjnemu budownictwu”. Podtrzymywał jednak swój jednoznacznie wrogi stosunek do Komunistycznej Partii Polski jako agentury obcego imperializmu. A. Dec, Narodowy socjalizm wobec komunizmu, „Narodowy Socjalista” 1933, nr 3.

89 A. Dębiec, Narodowy..., s. 32, 38.

90 A. D-ec, Hitler u władzy, „Narodowy Socjalista” 1933, nr 3. 
i wola twórców, zorganizowanych świadomie" panuje nad historią, dlatego postulował „nieustanną rewolucję ducha”1.

Idealizm Dagnana nie był jednak zakorzeniony w religii. Choć zdarzało mu się postulować „oparcie [...] życia społeczeństw na zasadach [...] religijnych”92, to akcenty religijne były w jego twórczości praktycznie nieobecne. Uważał, że interesy Watykanu są „częstokroć sprzeczne z interesami żywotnemi poszczególnych narodów" ${ }^{\prime 93}$. Adam Laska twierdzi wręcz, że Dagnan osobiście był niewierzący ${ }^{94}$.

Punktem wyjścia poglądów Dagnana był nacjonalizm. Wspólnotę narodową uważał za najważniejszą (choć nie jedyną) formę organizacji społecznej. Naród definiował jako „indywidualność zbiorową opierającą się na czynnikach zarówno przyrodzonych (wspólne pochodzenie rasowo-plemienne, język, wspólne terytorjum) jak i psychicznych (tradycja wspólnej przeszłości, obyczaje, [...] świadomość narodowa)", jednak w praktyce utożsamiał naród ze społeczeństwem. Uważał, że społeczeństwa podobne są do „organizmów żyjących”, a „między gromadami ludzkiemi toczy się walka o byt”; pokojowe (jak podkreślał) współzawodnictwo narodów miało być źródłem „energji narodowej”. Dystansował się jednak od egoizmu narodowego - głosząc hasło „przez naród do ludzkości”, ujmował wspólnotę narodową w perspektywie uniwersalistycznej ${ }^{95}$. Nacjonalizm Dagnana niewolny był od akcentów antysemickich. Jak wyjaśniał: „(n)ie chodzi nam tu o rasowe różnice, lecz o [...] fatalny wpływ rozkładowej, nihilistycznej, ekskluzywnej psychiki żydowskiej"96.

Dagnan uważał, że epokę mu współczesną kształtowało współzawodnictwo nacjonalizmu i socjalizmu, jednak wojna światowa ujawniła kryzys jednego i drugiego - z jednej strony konstatował fiasko proletariackiego internacjonalizmu, z drugiej stwierdzał, że rosnąca współzależność narodów musi ograniczać egoizm narodowy. Jak pisał: „biegunowo sprzeczne z sobą dok-

91 K. Dębiec, Narodowy ruch..., s. 45; K. Dagnan, Nowe..., s. 61-63.

92 K. Dagnan, Nowe..., s. 63.

93 A. Dębiec, Narodowy..., s. 27-28.

94 A. Laska, Narodowa..., s. 156.

95 K. Dagnan, Nowe..., s. 13, 18-19, 21, 74. Platforma programowa grupy Dagnana w 1920 r. zakładała „wykluczenie wszelkiej zaborczości, imperjalizmu, szowinizmu”. $Z$ historji...

96 A. Dębiec, Narodowy..., s. 28. 
tryny [...] zostały wzajemnie ku sobie nagięte [...] - stwarzają podstawę pod nową syntezę, [...] stanowiącą punkt wyjścia nowego ruchu polityczno-społecznego" ${ }^{97}$. W ten sposób miały powstać warunki dla narodzin narodowego socjalizmu. Jako cztery zasadnicze pryncypia Dagnan wymieniał: „uznanie narodu za organizm społeczny, dążenie do społecznej przebudowy ustroju gospodarczego, podporządkowanie interesu klasowego interesowi narodowemu, porzucenie materjalizmu dziejowego na rzecz pełnego poświęceń idealizmu" 98 .

Synteza takowa miała być konieczna zarówno z narodowej, jak i klasowej perspektywy. Dagnan uważał, że „[d]ążenia narodowe, mając na celu zapewnienie danej grupie etniczno-kulturalnej maximum szczęścia i dobrobytu, muszą [...] zespolić się ze społecznymi ruchami szerokich mas wytwórców-pracowników”, gdyż klasy pracujące stanowią „rdzeń organizmu narodowego”99. Zarazem w państwie słabym i zacofanym nie ma warunków do zapewnienia klasie robotniczej równouprawnienia, dobrobytu i rozwoju, dlatego w jej interesie jest umocnienie niepodległości ${ }^{100}$. Na tej podstawie głosił: „Polska - to rzecz ludowa" ${ }^{\prime 101}$. Mocno akcentował przy tym rozróżnienie między nacjonalizmem narodów panujących i uciskanych, jak również peryferyjne miejsce Polski w międzynarodowym podziale pracy ${ }^{102}$.

Z tych nacjonalistycznych przesłanek wynikał antykapitalizm Dagnana. Rozwój narodu polegać miał na nieustannym usuwaniu z organizmu narodowego grup nieprodukcyjnych (uważanych za pasożytnicze), zastępowaniu zdegenerowanych elit przez idących z duchem czasu wytwórców. Dagnan pisał, że „[c]o nie jest pracą i walką - musi być usunięte, jako balast społeczny, jako pasorzytnictwo [sic]”103. Kapitalizm jako ustrój „oparty na wszechwładzy prywatnego kapitału” uważał za schyłkowy, „niesprawiedliwy oraz wprowadza-

97 K. Dagnan, Nowe..., s. 6-7, 9-15.

98 A. Dębiec, Narodowy..., s. 39.

99 K. Dagnan, Nowe..., s. 54; por. A. Dec, Gdzie szukać sity obronnej państwa, na kim budować przyszłość narodu?, „Narodowy Socjalista” 1933, nr 4.

100 A. Dębiec, Narodowy..., s. 37.

101 K. Dębiec, Narodowy ruch..., s. 2-4.

102 K. Dagnan, Nowe..., s. 35.

103 Tamże, s. 23, 67. 
jący anarchię w życie społeczne i gospodarcze"104. Proponował zastąpienie go systemem, który „oprze się o zbiorowe, społeczne władanie całą wytwórczością gospodarczą i o społeczną organizację podziału dóbr i spożycia"105.

Socjalizm Dagnana był uwarunkowany i ograniczony jego nacjonalizmem - jak pisał: „Przebudowa społeczna nie może nadwyrężyć budowli narodowej państwa"106. Walka klas ograniczona była solidarnością narodową i rozumiana jako „spółzawodnictwo grup i klas społecznych w obrębie narodu”107. U zarania niepodległości Dagnan głosił, że priorytetem jest „twórcza, pozytywna praca niepodległościowo-państwowa”, dopiero gdy zagwarantowane będzie bezpieczeństwo kraju nastąpi „okres walki bezwzględnej o wcielenie w czyn naszych ideałów społecznych"108.

Co za tym idzie - narodowy socjalizm miał charakter na wskroś reformistyczny. Dagnan pochwalał „żywiołowy ruch mas robotniczych od dołu, skierowany przeciw doktrynerstwu przywódców i teoretyków marksizmu" ${ }^{109}$. Pisał: „Nie sądzimy, aby drogą jednorazowego przewrotu [...] można było [...] osiągnąć zupełne wyzwolenie socjalne”. W zamian proponował „droge ustawicznej a wytrwałej walki z panującym systemem wyzysku i krzywdy" ${ }^{110}$. Nie był to jednak reformizm socjaldemokratów, którym zarzucał faktyczne konserwowanie kapitalizmu ${ }^{111}$. Jako alternatywną wobec komunistycznej i socjaldemokratycznej drogę przemian społecznych proponował „organizowanie nowych komórek życia społecznego” w łonie społeczeństwa kapitalistycznego - $\mathrm{w}$ ten sposób równolegle $\mathrm{z}$ obalaniem starego ustroju postępowałoby oddolne tworzenie nowego. Dagnan wyobrażał sobie, że związki zawodowe, spółdzielnie i towarzystwa oświatowe, stopniowo rozrastając się, obejmą całokształt życia społecznego. Powstałe w ten sposób „Gminy Pracy”

104 D.K., Program społeczny NZR (Projekt nadesłany), „Sprawa Robotnicza” 1919, nr 36.

105 Nasze cele i drogi. Zasady programu społeczno-ekonomicznego, „Sprawa Robotnicza" 1918, nr 4.

106 K. Dagnan, Nowe..., s. 72.

107 Tamże, s. 22.

108 K. Dagnan, Rozważania programowe, „Sprawa Robotnicza” 1919, nr 12.

109 A. Dębiec, Narodowy..., s. 9-10; por. K. Dębiec, Narodowy ruch..., s. 8; K. Dagnan, Nowe..., s. 47-53.

110 K. Dagnan, Rozważania...

111 Nasze cele... 
miały delegować swych przedstawicieli do „Sejmu Pracy”, który wyłoniłby "Radę Pracy” jako organ zarządzający gospodarką i tak oto narodziłaby się Rzeczpospolita Pracy ${ }^{112}$.

Nowy ustrój z założenia miał być niedokończony, zmienny i ewoluujący. Choć planowano uspołecznienie gospodarki jego postępy uzależniano od dojrzałości warunków technicznych i gospodarczych. Uspołecznienie rozpocząć się miało od tych dziedzin, w których osobista inicjatywa właściciela przestała odgrywać już większą rolę. Natomiast dziedziny produkcji jeszcze nieskoncentrowane, nowe, wymagające ryzyka i indywidualnych zabiegów pozostawać miały prywatne tak długo, dopóki nie przekształciłyby się w towarzystwa akcyjne $^{113}$. Gospodarka uspołeczniona przeciwstawiana była kapitalizmowi państwowemu typu sowieckiego, kojarzonemu z dehumanizacją pracy. Różnica polegać miała na istnieniu „czynnika osobistego zainteresowania pracownika w produkcji”, dzięki czemu nastąpiłoby zespolenie interesu jednostki z interesem społecznym ${ }^{114}$.

Projektowany przez Dagnana ustrój miał mieć charakter „socjalistyczno-demokratyczny"115. Element demokratyczny dobitnie odróżniał polski narodowy socjalizm od faszyzmu. Dagnan konsekwentnie głosił konieczność „szerokiej demokratyzacji urządzeń politycznych naszego życia publicznego, demokratyzacji nie tylko formalnej [...] ale faktycznej”116. Podkreślał, że „Ludowa Polska Pracy” musi opierać się na „szeroko pojętej zasadzie autonomii i federacji w przeciwieństwie do centralizmu, zabijającego ducha i inicyatywę społeczną"117. Platforma programowa frakcji radykalnej NZR formułowała wiosną 1920 r. m.in. postulaty ustroju republikańsko-demokratycznego, jednoizbowego sejmu, pięcioprzymiotnikowych wyborów, decentralizacji, swobód obywatelskich, równouprawnienia mniejszości ${ }^{118}$. W latach 30. kierowana przez Dagnana PNS projektowała Narodowo-Socjalistyczną Rzeczpospolitą

112 K. Dagnan, Rozważania...; K. Dagnan, Nowe..., s. 68-69, 79-80. Nietrudno dostrzec w tej wizji echa „rzeczypospolitej spółdzielczej” Abramowskiego.

113 K. Dagnan, Nowe..., s. 71-74.

114 A. Dębiec, Upaństwowienie czy uspołecznienie, „Narodowy Socjalista” 1933, nr 9-12.

115 A. Dębiec, Narodowy..., s. 38.

116 K. Dębiec, Narodowy ruch..., s. 39; zob. też ibidem, s. 1, 9, 31-32, 43; A. Dębiec, Narodowy..., s. 6.

117 K. Dagnan, Rozważania...; por. K. Dagnan, Nowe..., s. 77.

118 Z historji... 
Pracy jako państwo „zbudowane na fundamencie swobody, praw i dobrobytu człowieka pracy"119. Wybory do Sejmu miały być powszechne, równe, bezpośrednie i tajne, a ordynacja wyborcza „winna [...] gruntować pełną swobodę i czystość aktu wyborczego". Prezydent powinien być wyłaniany w wyborach powszechnych, a rząd przez obie izby parlamentu ${ }^{120}$. Wysuwano też na wskroś demokratyczny program doraźny: likwidacja Berezy, amnestia dla więźniów politycznych, powrót do dawnej ordynacji wyborczej, nowe wybory do parlamentu, przywrócenie wolności obywatelskich ${ }^{121}$.

Kazimierz Dagnan był postacią nietuzinkową: uczestnik walk o niepodległość, społecznik, artysta. Jako działacz polityczny nie osiągnął większych sukcesów, ale był twórcą oryginalnej ideologii łączącej nacjonalizm, demokratyzm i reformistyczny socjalizm ${ }^{122}$. Ideom tym pozostał wierny przez cały czas swej działalności.

\section{BIBLIOGRAFIA}

\section{I. ŹRÓDEA}

Archiwalia

Archiwum Akt Nowych

zespół Ministerstwo Spraw Wewnętrznych

\section{Akty prawne}

Zarządzenie Prezesa Rady Ministrów, poz. 82, Monitor Polski nr 64 z 18 marca 1932 r.

119 Od Redakcji, „Trybuna Ludu” nr 1 (1934); Polski socjalizm narodowy, „Narodowy Socjalista" nr 4 (1935).

120 Nowa Konstytucja, „Narodowy Socjalista” nr 5 (1935); J. Łagowski, Walka o treść, „Narodowy Socjalista” nr 1-2 (1934); R. Stański, Ewolucja demokracji (II), „Narodowy Socjalista" nr 2 (1933).

121 Naród czeka..., „Narodowy Socjalista” nr 12 (1935); AAN, zespół Urząd Wojewódzki Łódzki, sygn. 271/I-1, k. 25-27.

122 O aktualności tych idei świadczy fakt, że współczesne środowisko nacjonalistyczne „Praca Polska” podjęło się reedycji broszury Dagnana „Narodowy ruch robotniczy: jego rola w życiu Polski i proletariatu polskiego" (Praca Polska, 2018). 
Publikacje zwarte (źródłowe: publicystyka, dokumenty publikowane, opracowania)

Antoni Ciszak. Zarys biograficzny przywódcy wielkopolskich mas robotniczych. Poznań 1938.

Dagnan Kazimierz: Nowe drogi narodowo-społecznego rozwoju. Warszawa 1924.

[Dębiec K.]: Narodowy ruch robotniczy jego rola w życiu Polski i proletariatu polskiego, Warszawa 1922.

[Dębiec Andrzej], Komunizm bankrutuje! Warszawa 1937.

[Dębiec Andrzej], Narodowy socjalizm. Pabianice 1930.

Legionista Polski. Kalendarz N.K.N. na rok 1916. Kraków bdw.

Lista starszeństwa oficerów Legjonów Polskich $w$ dniu oddania Legjonów Polskich Wojsku Polskiemu (12 kwietnia 1917). Warszawa 1917.

Jan Malański, Pracownicze zwiqzzi zawodowe w Polsce. Warszawa 1934.

Zarzewie 1909-1920. Wspomnienia i materiaty. Oprac. Aleksandra Garlicka. Warszawa 1973.

\section{Prasa}

"Narodowy Socjalista” (1932-1937)

„Sprawa Robotnicza” (1918-1919)

\section{Materiały prasowe}

Bibliografia górska, „Wierchy” t. 29, 1960.

Franciszek Czuchra, Byłem uczestnikiem Zjazdu Połaczeniowego PTT z PTK, „Echo Beskidu" 1991, nr 3.

Czy my katolicy możemy głosować za Narod. Partja Robotnicza, "Głos Rolnika” 1922, nr 45.

Kazimierz Dagnan, Zarys historji ruchu zawodowego w Polsce, „Solidarność Pracy” 1927, nr 1.

Enpeerowskie karty, „Łodzianin” 1924, nr 23.

Konferencja z komisarzem powiatowym Kasy Chorych w Kaliszu, „Sprawa Ubezpieczeń Społecznych" 1928, nr 2.

Kronika, „Polska Sztuka Ludowa - Konteksty” t. 31 (1977), nr 2.

Narodowi socjaliści w Polsce, „Dziennik Białostocki” z 15 IV 1932.

Nie ma zmian na stanowisku dyrektora U.S., „Nowy Kurjer” 1938, nr 114.

Nowy Sącz w 2010 roku, „Rocznik Sądecki” 2011, t. XXXIX.

Partja Narodowych Socjalistów, „Ilustrowana Republika” 1932, nr 219.

Piśmiennictwo, „Wierchy” 1948, t. 18.

Piśmiennictwo, „Wierchy” 1949, t. 19.

Poczet Prezesów Oddziału PTTK „Beskid” w Nowym Saczu, „Echo Beskidu” 2001, nr 2.

Pomnik ofiar mordu, „Gazeta Powszechna” 1931, nr 258.

Powiatowa Kasa Chorych w Kaliszu, „Samorząd Terytorjalny i Ubezpieczenia Społeczne” (dodatek do „Kuriera Porannego” z 27 czerwca 1929 r.). 
Radykalizm, szowinizm, antysemityzm, „Ilustrowana Republika” 1932, nr 106.

Sprawozdanie z działalności Funduszu Bezrobocia za rok 1934 i I kwartał 1935. Warszawa MCMXXXV.

Stronnictwo Narodowych Socjalistów, „Ilustrowana Republika” 1932, nr 175.

Stronnictwo nar. socjalistów, „Ilustrowana Republika” 1932, nr 105.

Małgorzata Tarsa-Bielak, Nasza galeria, „Kurier Starosądecki” 2003, nr 133.

Uczczenie pamięci Medarda Downarowicza wiceprezesa Zarządu Głównego Z. R., „Naród i Wojsko" 1935, nr 20.

W sprawie insynuacyj „Robotnika”, „Solidarność Pracy” 1927, nr 1.

Wielki kongres „Orlęcia” w Częstochowie, „Praca” 1929, nr 50.

Wł. Wolert, Ruch wspótdzielczy, „Przedświt” 1919, nr 1-2.

$Z$ archiwalnej półki, „Beskid” 1994, nr 3.

Z archiwalnej pótki, „Beskid” 1999, nr 1.

Zjazd Kas Chorych, „Polak” 1925, nr 172.

Zjednoczenie Narodowego Obozu Pracy, „Demokrata” 1935, nr 12.

\section{OPRACOWANIA}

Aleksander T., Życie społeczne i przemiany kulturalne Nowego Sacza w latach 18701990, Kraków 1993.

Beiersdorf Z., Krasnowolski B., Przekształcenia urbanistyczne, architektura i sztuka, [w:] Dzieje miasta Nowego Sącza, t. II, Kraków 1993.

Bieniek J. , Wojskowy ruch oporu na Sądeczyźnie [!], „Rocznik Sądecki” 1971, t. XII.

Bujak W., Historia Stronnictwa Pracy (1937-1946-1950). Warszawa 1988.

Ciepłowski S., Pseudonimy autorów polskich piszacych o Warszawie w latach 1795-1944, „Almanach Muzealny” 1997, nr 1.

Dagnan K.,Piętnastolecie istnienia i działalności Towarzystwa Przyjaciół Sztuk Pięknych w Nowym Saczu, „Rocznik Sądecki” 1973, t. XIV.

Demel Cz., Krawulski J., Rzepa K., Działalność Narodowego Stronnictwa Robotników i Narodowej Partii Robotniczej w Wielkopolsce w latach 1917-1937, Warszawa-Poznań 1980.

Duda T., Powiatowy Komitet Narodowy w Nowym Saczu w latach 1915-1916, „Rocznik Sądecki" 2008, t. XXXVI.

Garlicka A., Organizacja akcji prasowej Naczelnego Komitetu Narodowego, „Rocznik Historii Czasopiśmiennictwa Polskiego" 1964, t. 3, z. 2.

Sosnowiecka „Iskra” w sprawozdaniach Kazimierza Dagnana (I-II 1915), „Rocznik Historii Czasopiśmiennictwa Polskiego" 1965, t. 4, z. 1.

Gawryszczak, M. Bronisław Wilhelm Pieracki (1895-1934). Biografia polityczna. Łódź 2014.

Gessing R., Zarys dziejów II gimnazjum w Nowym Saczu w okresie galicyjskim (l. 1908-1918), „Rocznik Sądecki” 1971, t. XII.

Giza J., Jak Sacz o swoich katyńczykach pamiętał, „Almanach Sądecki” 2001, nr 3.

Kustroniowcy, „Almanach Sądecki” 1995, nr 4. 
Grott O., Faszyści i narodowi socjaliści w Polsce. Kraków 2007.

Hass L., Wybory warszawskie 1918-1926. Postawy polityczne mieszkańców Warszawy w świetle wyników glosowania do ciał przedstawicielskich, Warszawa 1972.

Krupa J., Zarys pracy niepodległościowej w Nowym Sączu, „Rocznik Sądecki” 1939, t. I.

Laska A., Działalność Narodowej Partii Robotniczej na terenie Małopolski w latach 1920-1937, „Zeszyty Naukowe Politechniki Rzeszowskiej” 2005, nr 224.

Laska A., Narodowa Partia Robotnicza 1920-1937. Studia z dziejów ruchów społecznych w Drugiej Rzeczypospolitej, Rzeszów 2004.

Malinowska I., Polskie centrum parlamentarne w latach 1919-1926, „Przegląd Historyczny" 1990, nr 3-4.

Monasterska T., Narodowy Zwiq̨zek Robotniczy 1905-1920, Warszawa 1973.

Pająk J. Z., Z dziejów Polskiej Organizacji Narodowej (wrzesień-grudzień 1914), „Kieleckie Studia Historyczne" 1996, t. 14.

Przybylski H., Chrześcijańska Demokracja i Narodowa Partia Robotnicza w latach 1926-1937, Warszawa 1980.

Ruch zawodowy w Polsce. Zarys dziejów, red. Stanisław Kalabiński, Warszawa 1974.

Sitek A., Kazimierz Dagnan (1891-1986), „Rocznik Sądecki” 1997, t. XXV.

Sitek A., Życie kulturalne Sądeczyzny [!] (1964-1969), „Rocznik Sądecki” t. XII (1971).

Szczepanek A., Zygmunt Kubrak, Generał Józef Kustroń, „Rocznik Sądecki” 2011, t. XXXIX.

Tomasiewicz J., W kierunku nacjokracji. Tendencje autorytarne, totalistyczne i profaszystowskie w polskiej myśli politycznej (1933-1939): narodowcy - narodowi radykałowie - narodowi socjaliści. Katowice 2019.

Tomasiewicz J., Rewolucja Narodowa. Nacjonalistyczne koncepcje rewolucji społecznej w Drugiej Rzeczypospolitej, Warszawa 2013.

Totoń A., 50-lecie TPSP w Nowym Sq̨czu, „Almanach Muszyny” 2007.

Wawro J., Komisja Opieki nad Zabytkami, „Echo Beskidu” 1991, nr 3. 